\title{
Aquaculture Research
}

\section{Biofilm formation of Flavobacterium psychrophilum on various substrates}

\begin{tabular}{|r|l|}
\hline Journal: & Aquaculture Research \\
\hline Manuscript ID & ARE-OA-18-Mar-251.R1 \\
\hline Manuscript Type: & Original Article \\
\hline Date Submitted by the Author: & n/a \\
\hline Complete List of Authors: & $\begin{array}{l}\text { Ríos Castillo, Abel G.; Universidad Autónoma de Barcelona, Department of } \\
\text { Animal and Food Science } \\
\text { Thompson, Kim; Moredun Research Institute, Aquaculture Research Group } \\
\text { Adams, Sandra; University of Stirling, Institute of Aquaculture } \\
\text { Marín de Mateo, Mercedes; Universitat Autònoma de Barcelona, } \\
\text { Department of Animal and Food Science } \\
\text { Rodríguez Jerez, José J.; Universitat Autònoma de Barcelona, Department } \\
\text { of Animal and Food Science }\end{array}$ \\
\hline Keywords: & $\begin{array}{l}\text { Flavobacterium psychrophilum, biofilm formation, fluorescent microscopy, } \\
\text { substrates, fish farming systems, rainbow trout farms }\end{array}$ \\
\hline &
\end{tabular}

\section{SCHOLARONE ${ }^{\text {M }}$ \\ Manuscripts}

This is the peer reviewed version of the following article: Ríos-Castillo AG, Thompson KD, Adams A, Marín de Mateo M, Rodríguez-Jerez JJ. Biofilm formation of Flavobacterium psychrophilum on various substrates. Aquac Res.

2018;49:3830-3837, which has been published in final form at https://doi.org/10.1111/are.13849. This article may be used for non-commercial purposes in accordance With Wiley Terms and Conditions for self-archiving. 


\section{Biofilm formation of Flavobacterium psychrophilum on various substrates}

2

3 Abel Guillermo Ríos-Castillo ${ }^{\mathrm{a}}$, Kim D. Thompson ${ }^{\mathrm{b}}$, Alexandra Adams ${ }^{\mathrm{c}}$, Mercedes Marín de

$4 \quad$ Mateo $^{\mathrm{a}}$, José Juan Rodríguez-Jerez ${ }^{\mathrm{a}}$

5

6 a Departament de Ciència Animal i dels Aliments, Facultat de Veterinària, Universitat

7 Autònoma de Barcelona, CP 08193, Barcelona, Spain.

$8{ }^{b}$ Moredun Research Institute, Pentlands Science Park, Bush Loan, Penicuik EH26 0PZ, UK.

$9{ }^{\mathrm{c}}$ Institute of Aquaculture, School of Natural Sciences, University of Stirling, Stirling FK9

10 4LA, UK.

11

12 Corresponding author: Abel Guillermo Ríos-Castillo. Facultat de Veterinària, Universitat

13 Autònoma de Barcelona, Travessera dels Turons s/n. Bellaterra, 08193, Barcelona, Spain.

14 Phone: +34 935811448. E-mail: abelguillermo.rios@uab.cat 


\section{Abstract}

18 The ability of Flavobacterium psychrophilum to adhere to and form biofilms on different types of materials used on rainbow trout (Oncorhynchus mykiss) farms was evaluated in this study. F. psychrophilum NCIMB $1947^{\mathrm{T}}$, was inoculated onto a variety of different surfaces, including stainless steel, plastic, glass, wood and zinc pyrithione encapsulated antibacterial plastic. The samples were then cultured in a humidified chamber or transferred into fish tanks containing either (1) freshwater or (2) filtered lake water. The formation of biofilms was quantified by fluorescent microscopy. F. psychrophilum formed biofilms on all of the surfaces tested, however, the adherence of the bacterium to the antibacterial plastic was much lower than the attachment observed on the other surfaces, illustrating the bacteriostatic properties of this material for F. psychrophilum. Moreover, bacterial numbers were greater on the surfaces maintained in lake water compared to those maintained in freshwater. The mineral composition of the lake water may have been responsible for the increased bacterial adherence observed between the two types of water. Treatment of the water, regular cleaning of equipment and the use of antimicrobial material to house the fish may help reduce biofilm formation by F. psychrophilum in fish farming systems.

Key words

Flavobacterium psychrophilum, biofilm formation, fluorescent microscopy, substrates, fish farming systems, rainbow trout farms 


\section{Introduction}

The continuous use of water within a fish farm can act as a reservoir for pathogenic bacteria, and this can be a factor in the spread of disease within the farm (King, 2001; Cai \& Arias, 2017). In the aquatic environment, bacteria rarely occur in a planktonic form, and their presence is more likely to be associated with surface-associated microbial communities known as biofilms (Huq, Whitehouse, Grim, Alam \& Colwell, 2008; Nocker, Burr \& Camper, 2014; Satpathy, Sen, Pattanaik \& Raut, 2016). Biofilms are structured communities of bacterial cells adhered to inert or living surfaces and enclosed in a polymeric matrix produced by the bacteria, referred to as an extracellular polymer substance (EPS). Biofilm formation is beneficial to the bacteria, providing them with protection against desiccation, increased nutrient availability and is more resistant to antimicrobial agents than planktonic bacteria (Costerton, Stewart \& Greenberg, 1999; Srey, Jahid \& Ha, 2013; Satpathy et al., 2016). Biofilms are composed of a variety of microflora present in the water, capable of colonizing surfaces, which can then act as a reservoir for pathogenic bacteria. Pathogenic microorganisms within the biofilm can be shed from the biofilm and are able to cause a reoccurrence of disease in fish (King, 2001; Branda, Vik, Friedman \& Kolter, 2005; Nocker et al., 2014). Biofilm formation is important to many pathogenic bacterial species, especially those living in water, giving them a selective advantage by increasing their ability to persist under adverse environmental conditions (Duchaud et al., 2007). They can form on many of the materials found within aquaculture systems, appearing on the surfaces of water pipes and fish tanks, suspended matter, incubators, bio-filtration systems and even on the internal and external surfaces of the fish (King et al., 2004).

Bacteria belonging to genus Flavobacterium have been identified as a group of bacteria able to persist in a latent form in the aquatic environment (Waśkiewicz \& Irzykowska, 2014). F. psychrophilum is a Gram-negative, yellow-pigmented bacterium, 
67 responsible for causing cold water disease (CWD) (Borg, 1948; Holt, Rohovec \& Fryer, 1993), or rainbow trout fry syndrome (RTFS) (Lorenzen, 1994; Rangdale, 1995) in salmonids and other freshwater fish. The bacterium not only infects farmed fish, but can also affect wild fish, although disease outbreaks are apparently less severe in non-salmonids (Nematollahi, Decostere, Pasmans \& Haesebrouck, 2003). It is, currently, one of the main bacterial pathogens in reared and wild salmonids, causing substantial economic losses in salmonid fish farms worldwide, and hindering expansion of the salmonid aquaculture industry (Nematollahi et al., 2003; Bernardet \& Bowman, 2006). The bacterium grows in the aquatic environment in temperatures ranging between $4^{\circ} \mathrm{C}$ to $23^{\circ} \mathrm{C}$ (Holt, 1988). It has the ability to adhere to the skin, gut and eggs of fish and disease transmission studies suggest that reservoirs of the bacterium can be found within the water system of the fish farm (Madetoja, Dalsgaard \& Wiklund, 2002). It also has the ability to adhere to surfaces forming biofilms, and has been detected in sediment, river water, especially near outlet water from infected fish farms (Amita, Hoshino, Honma \& Wakabayashi, 2000; Álvarez, Secades, Prieto, McBride \& Guijarro, 2006; Sundell \& Wiklund, 2011).

As aquaculture facilities are particularly prone to the development of biofilms by $F$. psychrophilum, understanding the factors that influence biofilm formation could reduce the presence of this pathogenic bacterium within the fish farming system (Huq et al., 2008; Wietz, Hall \& Høj, 2009; Srey et al., 2013). Thus, the purpose of this study was to gain a better understanding of the survival of this bacterium in the aquatic environment and to examine the ability of $F$. psychrophilum to adhere to and form biofilms on different types of materials used by the salmonid aquaculture industry. Biofilm formation by $F$. psychrophilum was examined in the presence of tryptone yeast extract salts (TYES) broth, freshwater taken from the aquarium or water from a freshwater lake. 
92

93

\section{Materials and methods}

\subsection{Bacterial culture}

F. psychrophilum, strain NCIMB $1947^{\mathrm{T}}$, was obtained from a stock of cryopreservation beads (Cryoprotect; Technical Service Consultants Service Ltd. Lancashire, UK) stored at $-70^{\circ} \mathrm{C}$. The bacterium was grown in TYES broth (tryptone, 4.0 g; yeast extract, $0.4 \mathrm{~g} ; \mathrm{MgSO}_{4} .7 \mathrm{H}_{2} \mathrm{O}$, $0.5 \mathrm{~g} ; \mathrm{CaCl}_{2} .2 \mathrm{H}_{2} \mathrm{O}, 0.2 \mathrm{~g}$; distilled water, $1000 \mathrm{~mL}$; $\mathrm{pH} 7.2$; autoclaved for $20 \mathrm{~min}$ at $121^{\circ} \mathrm{C}$ ) under constant agitation at $140 \mathrm{rpm}$ (Kühner Shaker LT-W, Adolf Kühner AG, Switzerland) for $72-96 \mathrm{~h}$ at $15^{\circ} \mathrm{C}$. This culture was subsequently cultured on TYES agar plates (TYES broth with $15.0 \mathrm{~g} / \mathrm{L}$ bacteriological agar) and incubated for $96 \mathrm{~h}$ at $15^{\circ} \mathrm{C}$, from which bacterial colonies were taken and cultivated in TYES broth under agitation for $72-96 \mathrm{~h}$ at $15^{\circ} \mathrm{C}$ to obtain the bacterial culture used in the analysis.

\subsection{Test materials}

Four different types of material, e.g. stainless steel (type 1.4301, also known as grade 304) used as positive control (Fuster-Valls, Hernández, Marín de Mateo \& Rodríguez-Jerez, 2008), polyethylene (PE) plastic, silica glass, wood (Pinus sp.) and an antibacterial plastic [polypropylene (PP) containing micro-encapsulated zinc pyrithione] (Microlitix, Sant Cugat del Valles, Spain) were selected to assess their ability to support $F$. psychrophilum biofilm formation. The size of the material used was $4.0 \times 4.0 \mathrm{~cm}^{2}$, while the stainless steel surfaces consisted of discs with a diameter of $2.0 \mathrm{~cm}$ and a thickness of $1.2 \mathrm{~mm}$. Prior to performing the study, the surfaces were cleaned, disinfected and autoclaved at $121^{\circ} \mathrm{C}$ for $15 \min$ (RíosCastillo, González-Rivas \& Rodríguez-Jerez, 2017), except the antibacterial plastic, which was only cleaned with 70\% isopropyl alcohol (2-propanol) before use so as not to interfere with its antibacterial properties. 
117

118

119

120

121

122

123

124

125

126

127

128

129

130

131

132

133

134

135

136

137

138

139

140

141

\subsection{Experimental design}

The formation of biofilms on the different test materials was performed by incubating the supports in a F. psychrophilum suspension under two different sets of test conditions.

(a) In the first test, all surfaces were inoculated with $16 \mu \mathrm{L} / \mathrm{cm}^{2}$. The number of live and dead bacteria was determined using the LIVE/DEAD staining kit with a bacterial concentration on the surfaces of $2.01 \times 10^{6}$ live cells $/ \mathrm{cm}^{2}$ and $4.79 \times 10^{1}$ of dead $/$ damaged cells $/ \mathrm{cm}^{2}$. The surfaces inoculated were placed in Petri dishes, which were then placed into a humidified chamber $(30 \times 22 \times 14 \mathrm{~cm})$ maintained at a saturated relative humidity of $\geq 90 \%$ using pieces of paper towel moistened with sterile distilled water (Wiklund \& Dalsgaard, 2003; FusterValls et al., 2008; International Organization for Standardization, 2011). The bacteria were incubated on these surfaces for $48 \mathrm{~h}$ at $15^{\circ} \mathrm{C}$. After this time, the excess liquid was removed from each surface and $50 \mu \mathrm{L}$ of TYES broth was added to the surface of the stainless steel disc and $255 \mu \mathrm{L}$ to the other surfaces with a sterile pipette. These were then incubated for a further $48 \mathrm{~h}$ at $15^{\circ} \mathrm{C}$ before the degree of biofilm formation on each support was assessed using fluorescence microscopy.

(b) The ability of F. psychrophilum to form biofilms on the different surfaces (stainless steel, plastic, glass, antibacterial plastic and wood) was also assessed using freshwater collected from either a freshwater aquarium [Aquaculture Research Facility (ARF), Institute of Aquaculture, University of Stirling], or from a freshwater lake (Airthrey Loch, University of Stirling). The water samples taken from the aquarium and the lake were filtered through a $0.45 \mu \mathrm{m}$ filter (Millipore Co., Billerica, Ma, U.S.A.) prior to use. The various supports were incubated with $F$. psychrophilum $\left(2.14 \times 10^{6}\right.$ of viable cells $/ \mathrm{cm}^{2}$ and $7.41 \times 10^{1}$ cells $/ \mathrm{cm}^{2}$ of dead or injured cells) for $72 \mathrm{~h}$. After this time, the excess liquid was removed from each surface and the surfaces were attached onto the side of plastic fish tanks $(20 \times 40 \times 22 \mathrm{~cm})$ with Blu-Tack ${ }^{\mathrm{TM}}$ malleable rubber adhesive (Bostik Ltd, Leicester, UK). The tanks contained: 
(i) $100 \mathrm{~mL}$ of TYES broth with 10 litres of freshwater from the aquarium (dechlorinated, 143 mains water), or (ii) $100 \mathrm{~mL}$ of TYES broth with 10 litres of freshlake water. The surfaces were maintained in the tanks for $96 \mathrm{~h}$ at $15-16^{\circ} \mathrm{C}$. After this incubation period, the test materials were removed from the tanks, washed carefully with distilled water, taking care not to disturb the biofilm on the surfaces and these were then examined by fluorescence microscopy using the LIVE/DEAD staining kit. Live/Dead BacLight Bacteria Viability Kit (Molecular Probes, Europe BV) was used to determine the initial number of live bacteria present in the bacterial cultures used for the studies and to assess the number of live bacteria present on surfaces after $96 \mathrm{~h}$ of incubation with F. psychrophilulm. The LIVE/DEAD staining kit is composed of two nucleic acidbinding stains: $\mathrm{SYTO}^{\circledR}$ 9, penetrating all bacterial membranes and stains the cells green, and manufacturer's instructions.

The stainless steel discs were stained with $20 \mu \mathrm{L}$ and plastic, glass, wood and the antibacterial

\subsection{Assessing the number of live bacteria by fluorescence microscopy}

propidium iodide which only penetrates cells with damaged membranes, producing red

fluorescing cells when the cells are damaged or dead. The kit was used according to plastic with $100 \mu \mathrm{L}$. Stained surfaces were left in the dark for $15 \mathrm{~min}$ at $22^{\circ} \mathrm{C}$ to allow the stains to penetrate. Eight images were acquired from every surface evaluated using a fluorescence microscope IX70 (Olympus Optical, Tokyo, Japan) equipped with a mercury lamp, and two filters: (1) filter A (excitation 470-490 nm, emission 515-550 nm) and (2) filter B (excitation $510-550 \mathrm{~nm}$, emission $>590 \mathrm{~nm}$ ). The same microscopic parameters, input calibration and image acquisition were used throughout and images were analysed using Cytovision $^{\circledR}$ software, version 2.51 (Applied Imaging, Sunderland, Tyne \& Wear, UK). Cell counts and bacteria size (i.e. minimum and maximum diameter and area) were automatically 
167 measured as a colour scale interpretation using Soft Imaging System ${ }^{\text {TM }}$ program, AnalySIS ${ }^{\circledR}$

168 version $3.2(\mathrm{GmbH}$, Munich, Germany).

169

170

\subsection{Water analysis}

171 Prior to performing the fresh water studies, the mineral composition of the water was

172 analysed from both water sources. To do this, 10 litres of freshwater was obtained from the

173 aquarium facility and directly from the freshwater lake, both of which were filtered through a

$1740.45 \mu \mathrm{m}$ filter. The samples of water were then analysed by inductively coupled plasma mass

175 spectrometry (ICP-MS) to determine the concentration of their mineral content. This analysis

176 was performed by the Water Quality Laboratory, Institute of Aquaculture, University of

177 Stirling.

178

\subsection{Statistical analysis}

180 Each analysis comparing biofilm formation on the various supports was repeated three times

181 and each test material surface was analysed in triplicate $(n=9)$. The statistical software

182 package $\mathrm{SAS}^{\circledR}$ v 9.1.3.4 (Institute Inc, North Carolina, USA) was used for the statistical

183 analysis. The assumption of normality of the data was carried out using the Shapiro-Wilk test.

184 Statistical analysis was performed on data between cells counted on the various surfaces

185 under the different test condition using an analysis of variance (ANOVA). Student-Newman-

186 Keuls post hoc test was used to test the significance of differences between live and dead or

187 injured bacteria on the surfaces, where $p \leq 0.05$ was considered significant.

\section{Results}

\subsection{Biofilm formation by $F$. psychrophilum}


191

192

193

194

195

196

In the first study, in which a suspension of $F$. psychrophilum in TYES was incubated onto the various supports in a humidified chamber, the live-cell counts obtained using the LIVE/DEAD kit showed a similar amount of live and dead bacteria attached to the various supports (Table 1). There was no statistical difference obtained in the level of adherence or biofilm formation on stainless steel $\left(1.41 \times 10^{6}\right.$ live cells $\left./ \mathrm{cm}^{2}\right)$, plastic $\left(9.12 \times 10^{5}\right.$ live cells $\left./ \mathrm{cm}^{2}\right)$ or glass $\left(8.32 \times 10^{5}\right.$ live cells $\left./ \mathrm{cm}^{2}\right)$ after $96 \mathrm{~h}$ of incubation. Whereas adherence of the bacterium to the antibacterial plastic surface was significantly lower $(p<0.05)$ than observed on the other materials with respect to both live $\left(6.46 \times 10^{3}\right.$ cells $\left./ \mathrm{cm}^{2}\right)$ and $\mathrm{dead} /$ injured cells $\left(1.10 \times 10^{4}\right.$ cells $\left./ \mathrm{cm}^{2}\right)$. Also, an increase in the number of cells $/ \mathrm{cm}^{2}$ of dead or injured cells was observed on all test materials, increasing from an initial concentration of $4.79 \times 10^{1}$ cells $/ \mathrm{cm}^{2}$ to $10^{4}$ or $10^{5}$ cells $/ \mathrm{cm}^{2}$ after $96 \mathrm{~h}$ of being introduced on to the support.

\subsection{Biofilm formation of $F$. psychrophilum in aquarium or lake water}

The degree of bacterial attachment to the various supports (stainless steel, plastic, glass, wood and antibacterial plastic) after $96 \mathrm{~h}$ at $15-16^{\circ} \mathrm{C}$, in either the aquarium water or the lake water, is presented in Table 2. Higher levels of live bacteria $(p<0.05)$ were present in the freshwater from the aquarium adhering to stainless steel $\left(8.68 \times 10^{4}\right.$ cells $\left./ \mathrm{cm}^{2}\right)$, plastic $(1.09 \mathrm{x}$ $10^{5}$ cells $\left./ \mathrm{cm}^{2}\right)$ (Figure 1c), glass surfaces $\left(8.52 \times 10^{4}\right.$ cells $\left./ \mathrm{cm}^{2}\right)$ (Figure $\left.1 \mathrm{~d}\right)$ and wood $(1.11 \mathrm{x}$ $10^{5}$ cells $\left./ \mathrm{cm}^{2}\right)$ compared to the antibacterial plastic $\left(2.88 \times 10^{2}\right.$ cells $\left./ \mathrm{cm}^{2}\right)$. The results with the water obtained from freshwater lake showed significantly higher levels of live-cells $(p<0.05)$ attached to stainless steel $\left(2.30 \times 10^{5}\right.$ cells $\left./ \mathrm{cm}^{2}\right)$, plastic $\left(2.98 \times 10^{5}\right.$ cells $\left./ \mathrm{cm}^{2}\right)$ and glass $(2.41$ x $10^{5}$ cells $\left./ \mathrm{cm}^{2}\right)$ compared with the wood $\left(1.38 \times 10^{5}\right.$ cells $\left./ \mathrm{cm}^{2}\right)$ (Figure 1e) or the antibacterial plastic surface $\left(6.03 \times 10^{3}\right.$ cells $\left./ \mathrm{cm}^{2}\right)$ (Figure 1f). Figure 2 shows the values in parts per billion ( $\mathrm{ppb}$ ) of sodium, magnesium, potassium and calcium of freshwater aquarium and in lake water used to evaluate the biofilm formation of P. psychrophilum. According to 
these results, the concentrations of all minerals analysed in the lake water were higher than

217 those obtained from the freshwater aquarium. The highest mineral element concentration for the lake water was calcium (13760.0 ppb), and the lowest magnesium (1022.0 ppb). In the case of aquarium water, the highest value, although lower than that found in the lake water was also calcium (7118.5 ppb), while the potassium concentration was the lowest (211.0 ppb).

\subsection{Antimicrobial properties of antibacterial plastic [poly-propylene (PP) containing} micro-encapsulated zinc pyrithione]

The results of this study indicate that the antibacterial properties of zinc pyrithione under saturated relative humidity of $\geq 90 \%$ had $2.34 \log _{10}$ cells $/ \mathrm{cm}^{2}$ fewer bacteria attached relative to the positive control, $2.48 \log _{10}$ cells $/ \mathrm{cm}^{2}$ in freshwater and $1.58 \log _{10}$ cells $/ \mathrm{cm}^{2}$ in lake water, while only a minimal reduction was observed for other surfaces under the various conditions.

\section{Discussion}

When environmental conditions are unfavourable, aquatic bacteria are subjected to a rapid change in nutrient availability and must therefore adapt accordingly in order to be able to survive under these adverse conditions. For example, cells undergo reduced cell division, the humidity chamber, some of the dead/injured bacteria became rounded in appearance. The morphological changes in F. psychrophilum cells observed here have also been reported by 
241 In this study, these changes were observed after only $96 \mathrm{~h}$ incubation suggesting that this

242 adaptation may be accelerated during the growth of the bacteria on the surfaces compared to

243 growth in TYES broth, reflecting the environment stress experience by the bacteria during

244 biofilm formation. This reduction in bacterial size during biofilm formation, which in mature

245 stages of biofilm contained more damaged cells (dead or non-viable) than live cells, has also

246 been reported by Roszak \& Colwell (1987); Boulos, Prevost, Barbeau, Coallier \& Desjardins,

247 (1999); Chmielewski \& Frank (2003); and Fuster-Valls et al. (2008). The results also suggest

248 that high levels of humidity and the use of TYES broth could favour the adhesion and biofilm

249 formation of F. psychrophilum. According to Ehrlich, Miller \& Walker (1970), the survival of

250 Flavobacterium sp. is not affected by high conditions of humidity (up to 99\%), but can be

251 affected by a lack of nutrients. Under dry conditions, Fuster-Valls et al. (2008) observed a

252 considerable reduction in the level of bacterial attachment by the cells, with some cells

253 appearing injured, and non-culturable in culture medium. They were still considered to have

254 the potential to cause disease outbreaks, however. Humid areas within the fish farming

255 system, ideal for bacterial growth, can favour the adhesion and biofilm formation by $F$.

256 psychrophilum, and microorganisms present on equipment and surfaces within the fish farm,

257 may survive there for prolonged periods of time (Lee Wong, 2004).

258

The results of the mineral analysis may explain the high levels of bacteria seen adhering to the surfaces in the presence of the lake water compared to the aquarium water (Figure 2). These values were statistically different $(p<0.05)$ for the live cell counts attached to the stainless steel, glass and antibacterial zinc pyrithione surfaces. These results are in accord with Fletcher (1988), who observed that cationic metal concentrations of sodium, calcium, magnesium minimize the repulsive forces between the bacterial cell and surfaces, having an influence on the ability of bacteria to adhere to surfaces and form biofilms. The 
attachment; in fact, a deficiency of certain nutrients may increase the ability of bacteria to form biofilms, though the concentration of nutrients necessary for bacterial development is low (Mattila-Sandholm \& Wirtanen, 1992; Percival \& Walker, 1999). The presence of organic and inorganic material can also influence biofilm formation by bacteria within the Flavobacterium genus. Staroscik, Hunnicutt \& Nelson (2007) observed that the addition of $\mathrm{Ca}^{2+}$ and $\mathrm{Mg}^{2+}$ or glucose to the culture medium, or the presence of mucus from salmon skin induced the formation of biofilms by Flavobacterium columnare. Likewise, the environment can represent a reservoir of $F$. psychrophilum, since the ability of this microorganism to adhere to surfaces could explain the bacterium's survival under adverse conditions. The fact that water can act as a source of infection implies that $F$. psychrophilum is able to survive outside its host under conditions of starvation (Vatsos, Thompson \& Adams, 2001). Madetoja, Nystedt \& Wiklund (2003) found that the virulence of $F$. psychrophilum was maintained for at least seven days after transferring the bacteria to freshwater, and the bacterium's survival increased with the addition of nutrient-containing sediments; thereby $F$. psychrophilum can readily spread from infected fish to uninfected ones in recirculating aquaculture systems. The differences in bacterial counts (expressed in decimal logarithms, $\log _{10}$ ) of live-cells adhered to plastic, glass, wood or antibacterial plastic were compared with the number of livecells attached to the stainless steel surfaces, used as a control (Table 3). According to Japanese Standard JIS Z 2801 (Japanese Standards Association, 2010) and ISO 22196 (International Organization for Standardization, 2011) surfaces with antibacterial properties must demonstrate a reduction in bacterial attachment equal to or higher than $2 \log _{10}$ of that determined for the control surface. The zinc pyrithione antibacterial plastic showed a high efficiency in preventing bacterial adherence when it was tested under the humidity conditions (2.34 log) or under the aquarium water condition $(2.48 \mathrm{log})$. On the other hand, when it was tested under the lake water condition, the efficiency was lower $(1.58 \log )$ (Table 3). This 
could be explained because the high mineral concentration of sodium, magnesium, potassium, and calcium in the lake water may prevent the adequate action of zinc-pyrithione. It has been earlier reported that higher level of minerals favour the adherence of Flavobacterium and biofilm formation (Madetoja et al., 2003; Staroscik et al., 2007). The antibacterial action of zinc pyrithione in preventing the adherence of cells is favoured by the use freshwater used in fish farms and is partly inhibited by the presence of water with a high mineral content. Zinc pyrithione interacts with the membrane phospholipids in bacteria, inhibiting membrane transport of substrates and decreasing intracellular ATP levels by inhibiting ATP synthesis causing a lethal toxicity of bacterial cells (Qian, Chen \& Xu, 2013).

As established from the genome analysis of F. psychrophilum, the bacterium has the ability to form biofilms and store cyanophicin, which could explain the bacterium's prolonged survival outside its host (Duchaud et al., 2007) and the spread of disease by this bacterium through the aquatic environment (Madetoja et al., 2002; Nematollahi et al., 2003). The ability of this bacterium to adhere to surfaces and form biofilms may explain why it is less susceptible to antimicrobial treatment. Sundell \& Wiklund (2011) observed an increased antimicrobial resistance in $F$. psychrophilum biofilms containing high bacterial cell densities $\left(>10^{7} \mathrm{CFU} / \mathrm{mL}\right)$. These characteristics, together with adherent properties of $F$. psychrophilum may explain the subsequent transmission of this bacterium to fish, and probably contribute to its dissemination in salmonid fish farms, representing a significant risk in the development of the salmonid aquaculture (Nematollahi et al., 2003; Barnes \& Brown, 2011). Zinc pyrithione, is widely used as an antifouling agent in paints and exhibit a high antimicrobial effects against biofilm bacteria (Konstantinou \& Albanis, 2004; Ciriminna, Bright \& Pagliaro, 2015). The commercial cost of zinc pyrithione, used in a concentration of $2.0 \%$ as biocide and antifouling is approximately US\$2.50 - US\$ 3.50 to cover each $100 \mathrm{~m}^{2}$ of fish-farm environments. 
316 from this bacterium justifies the investment. Thus, the use of materials that inhibit bacterial

317 growth such as zinc pyrithione may offer alternative ways to reduce the spread of $F$.

318 psychrophilum within the fish farming system as well as other bacterial species involved in

319 disease outbreaks.

320

321

\section{Conclusions}

322 This study suggests that $F$. psychrophilum has the ability to adhere to and form biofilms on

323 materials used within aquaculture systems such as stainless steel, plastic, glass and wood at

324 saturated relative humidity levels of $\geq 90 \%$ and in freshwater aquarium or lake water.

325 Procedures such as water treatment, regular sanitation of equipment, and the use of

326 antimicrobial surfaces may be useful in preventing biofilm formation in fish farming systems,

327 and in turn preventing disease outbreaks caused by this bacterium.

328

329

\section{Acknowledgments}

330 The authors wish to acknowledge technical support in the laboratory and in the Aquarium

331 Research Facilities at the Institute of Aquaculture, University of Stirling, where this work was

332 carried out.

\section{Conflict of interest}

335 The authors declare no conflicts of interest.

\section{References}


Álvarez, B., Secades, P., Prieto, M., McBride, M.J., \& Guijarro, J.A. (2006). A mutation in Flavobacterium psychrophilum tlpB inhibits gliding motility and induces biofilm formation. Applied and Environmental Microbiology, 72, 4044-4053. doi:10.1128/AEM.00128-06

Amita, K., Hoshino, M., Honma, T., \& Wakabayashi, H. (2000). An investigation on the distribution of Flavobacterium psychrophilum in the Umikawa River. Fish Pathology, 35, 193-197. doi:10.3147/jsfp.35.193

Arias, C.R., LaFrentz, S., Cai, W., \& Olivares-Fuster, O. (2012). Adaptive response to starvation in the fish pathogen Flavobacterium columnare: cell viability and ultrastructural changes. BMC Microbiology, 12, 266. doi:10.1186/1471-2180-12-266

Barnes, M.E., \& Brown, M.L. (2011). A review of Flavobacterium psychrophilum biology, clinical signs, and bacterial cold water disease prevention and treatment. The Open Fish Science Journal, 4, 40-48. doi:10.2174/1874401X01104010040

Bernardet, J.-F., \& Bowman, J. P. (2006). The genus Flavobacterium. In M. Dworkin, S. Falkow, E. Rosenberg, K.-H. Schleifer \& E. Stackebrandt (Eds.), The Prokaryotes: a Handbook on the Biology of Bacteria (pp. 481-531). New York: Springer.

Borg, A.F. (1948). Studies on myxobacteria associated with diseases in salmonid fishes. Ph.D. Thesis. University of Washington. Seattle, WA, USA.

Boulos, L., Prévost, M., Barbeau, B., Coallier, J., \& Desjardins, R. (1999). LIVE/DEAD ${ }^{\circledR}$ BacLight $^{\mathrm{TM}}$ : application of a new rapid staining method for direct enumeration of viable and total bacteria in drinking water. Journal of Microbiological Methods, 37, 77-86. doi:10.1016/S0167-7012(99)00048-2

Branda, S.S., Vik, A., Friedman, L., \& Kolter, R. (2005). Biofilms: the matrix revisited. Trends in Microbiology, 13, 20-26. doi:10.1016/j.tim.2004.11.006 
Cai, W., \& Arias, C.R. (2017). Biofilm Formation on Aquaculture Substrates by Selected Bacterial Fish Pathogens. Journal of Aquatic Animal Health, 29, 95-104. doi:10.1080/08997659.2017.1290711

Chmielewski, R., \& Frank, J. (2003). Comprehensive Reviews in Food Science and Food Safety, 2, 22-32. doi:10.1111/j.1541-4337.2003.tb00012.x

Ciriminna, R., Bright, F.V., \& Pagliaro, M. (2015). Ecofriendly Antifouling Marine Coatings. ACS Sustainable Chemistry \& Engineering, 3, 559-565. doi:10.1021/sc500845n

Costerton, J.W., Stewart, P.S., \& Greenberg, E.P. (1999). Bacterial biofilms: A common cause of persistent infections. Science, 284, 1318-1322. doi:10.1126/science.284.5418.1318

Duchaud, E., Boussaha, M., Loux, V., Bernardet, J.F., Michel, C., Kerouault, B., Mondot, S., Nicolas, P., Bossy, R., Caron, C., Bessières, P., Gibrat, J., Claverol, S., Dumetz, F., Henaff, M., \& Benmansour, A. (2007). Complete genome sequence of the fish pathogen Flavobacterium psychrophilum. Nature Biotechnology, 25, 763-769. doi:10.1038/nbt1313

Ehrlich, R., Miller, S., \& Walker, R.L. (1970). Effects of Atmospheric Humidity and Temperature on the Survival of Airborne Flavobacterium. Applied Microbiology, 20, $884-887$.

Fletcher, M. (1988). Attachment of Pseudomonas fluorescens to glass and influence of electrolytes on bacterium-substratum separation distance. Journal of Bacteriology, 170, 2027-2030. doi:10.1128/jb.170.5.2027-2030.1988

Fuster-Valls, N., Hernández-Herrero, M., Marín de Mateo, M., \& Rodríguez-Jerez, J.J. (2008). Effect of different environmental conditions on the bacteria survival on stainless steel surfaces. Food Control, 9, 308-314. doi:10.1016/j.foodcont.2007.04.013 
Holt, R.A. (1988). Cytophaga psychrophila, the causative agent of bacterial cold-water disease in salmonid fish. Ph.D. Thesis. Oregon State University. Corvallis, OR, USA.

Holt, R.A., Rohovec, J.S., \& Fryer, J.L. (1993). Bacterial cold-water disease. In V. Inglis, R.J. Roberts, N.R. Bromage (Eds.), Bacterial Diseases of Fish (pp. 3-23). Oxford: Blackwell Scientific Publications.

Huq, A., Whitehouse, C.A., Grim, C.J, Alam, M., \& Colwell, R.R. (2008). Biofilms in water, its role and impact in human disease transmission. Current Opinion in Biotechnology, 19, 244-247. doi:10.1016/j.copbio.2008.04.005

International Organization for Standardization (2011). Measurement of antibacterial activity on plastics and other non-porous surfaces, ISO 22196:2011.

Japanese Standards Association (2010). Antimicrobial products-Test for antimicrobial activity and efficacy. Japanese Industrial Standard, JIS Z 28010.

King, R.K. (2001). The Presence of Bacterial Pathogens in Recirculating Aquaculture System Biofilms and their Response to Various Sanitizers. Ph.D. Thesis. Virginia Polytechnic Institute and State University. Blacksburg, VA, USA.

King, R.K., Flick Jr., G.J., Pierson, M.D., Smith, S.A., Boardman, G.D., \& Coale, C.W.J. (2004). Identification of bacterial pathogens in biofilms of recirculating aquaculture systems. Journal of Aquatic Food Product Technology, 13, 125-133. doi:10.1300/J030v13n01_11

Konstantinou, I.K., \& Albanis, T.A. (2004). Worldwide occurrence and effects of antifouling paint booster biocides in the aquatic environment: a review. Environment International, 30, 235-248. doi:10.1016/S0160-4120(03)00176-4

Lee Wong, A.C. (2004). Biofilm formation and control in food processing environments. In R. Jordan, D. Williams, U. Charaf (Eds.), Advances in Biofilm Science and Engineering (pp. 245-281). Bozeman: Cytergy Publishing. 
Lorenzen, E. (1994). Studies on Flexibacter psychrophilus in relation to rainbow trout fry syndrome (RTFS). Ph.D. Thesis. Royal Veterinary and Agricultural University. Copenhagen, Denmark.

Madetoja, J., Dalsgaard, I., \& Wiklund, T. (2002). Occurrence of Flavobacterium psychrophilum in fish-farming environment. Diseases of Aquatic Organisms, 52, 109118. doi:10.3354/dao052109

Madetoja, J., Nystedt, S., \& Wiklund, T. (2003). Survival and virulence of Flavobacterium psychrophilum in water microcosms. FEMS Microbiology Ecology, 43, 217-223. doi:10.1111/j.1574-6941.2003.tb01061.x

Mattila-Sandholm, T., \& Wirtanen, G. (1992). Biofilm formation in the industry: a review. Food Reviews International, 8, 573-603. doi:10.1080/87559129209540953

Nematollahi, A., Decostere, A., Pasmans, F., \& Haesebrouck, F. (2003). Flavobacterium psychrophilum infections in salmonid fish. Journal of Fish Diseases, 26, 563-574. doi:10.1046/j.1365-2761.2003.00488.x

Nocker, A., Burr, M., \& Camper, A. (2014). Pathogens in Water and Biofilms. In S.L. Percival, M.V. Yates, D.W. Williams, R.M. Chalmers, N.C. Gray (Eds.), Microbiology of Waterborne Diseases (pp. 3-32). London: Academic Press.

Percival, S.L, \& Walker, J.T. (1999). Potable Water and Biofilms: A Review of the Public Health Implications. Biofouling, 14, 99-115. doi:10.1080/08927019909378402

Qian, P.Y., Chen, L., \& Xu, Y. (2013). Mini-review: Molecular mechanisms of antifouling compounds. Biofouling, 29, 381-400. doi:10.1080/08927014.2013.776546

Rangdale, R.E. (1995). Studies on Rainbow Trout Fry Syndrome (RTFS). Ph.D. Thesis. University of Stirling. Scotland, UK.

Ríos-Castillo, A.G., González-Rivas, F., \& Rodríguez-Jerez, J.J. (2017). Bactericidal Efficacy of Hydrogen Peroxide-Based Disinfectants against Gram-Positive and Gram-Negative 
Bacteria on Stainless Steel Surfaces. Journal of Food Science, 82, 2351-2356.

440

441

442

443

444

445

446

447

448

449

450

451

452

453

454

455

456

457

458

459

460

461

462 doi:10.1111/1750-3841.13790

Roszak, D.B., \& Colwell, R.R. (1987). Survival strategies of bacteria in the natural environment. Microbiological Reviews, 51, 365-379.

Satpathy, S., Sen, S.K., Pattanaik, S., \& Raut, S. (2016). Review on bacterial biofilm: An universal cause of contamination. Biocatalysis and Agricultural Biotechnology, 7, 56-66. doi:10.1016/j.bcab.2016.05.002

Srey, S., Jahid, I.K., \& Ha, S.D. (2013). Biofilm formation in food industries: A food safety concern. Food Control, 31, 572-585. doi:10.1016/j.foodcont.2012.12.001

Staroscik, A.M., Hunnicutt, D.W., \&Nelson, D.R. (2007). The influence of culture conditions on biofilm formation in Flavobacterium columnare. Flavobacterium 2007 Workshop (pp. 21). National Conservation Training Center. Shepherdstown, WV, USA.

Sundell, K., \& Wiklund, T. (2011). Effect of biofilm formation on antimicrobial tolerance of Flavobacterium psychrophilum. Journal of Fish Diseases, 34, 373-383. doi:10.1111/j.1365-2761.2011.01250.x

Vatsos, I.N., Thompson, K.D., \& Adams, A. (2001). Adhesion of the fish pathogen Flavobacterium psychrophilum to unfertilized eggs of rainbow trout (Oncorhynchus mykiss) and n-hexadecane. Letters in Applied Microbiology, 33, 178-182. doi:10.1046/j.1472-765x.2001.00980.x

Vatsos, I.N., Thompson, K.D., \& Adams, A. (2003). Starvation of Flavobacterium psychrophilum in broth, stream water and distilled water. Diseases of Aquatic Organisms, 56, 115-126. doi:10.3354/dao056115

Waśkiewicz, A., \& Irzykowska, L. (2014). Flavobacterium spp. - Characteristics, Occurrence, and Toxicity. In C.A. Batt, M.L. Tortorello (Eds.), Encyclopedia of Food Microbiology (pp. 938-942). Oxford: Academic Press. 
463 Wietz, M., Hall, M.R., \& Høj, L. (2009). Effects of seawater ozonation on biofilm

464 development in aquaculture tanks. Systematic and Applied Microbiology, 32, 266-277.

465 doi:10.1016/j.syapm.2009.04.001

466 Wiklund, T., \& Dalsgaard, I. (2003). Association of Flavobacterium psychrophilum with

467 rainbow trout (Oncorhynchus mykiss) kidney phagocytes in vitro. Fish \& Shellfish

468 Immunology, 15, 387-395. doi:10.1016/S1050-4648(03)00009-3

469 
471 Table 1. Adherence and biofilm formation of Flavobacterium psychrophilum (cells $/ \mathrm{cm}^{2}$ ) on

472 stainless steel, plastic, glass, and antibacterial plastic surfaces after $96 \mathrm{~h}$ of incubation in

473 humidity test condition.

\begin{tabular}{ccc}
\hline \multirow{2}{*}{ Surfaces } & \multicolumn{2}{c}{ Cells $^{\dagger}$} \\
\cline { 2 - 3 } & Live & Injured or dead \\
\hline Stainless steel & $1.41 \times 10^{6} \pm 0.37^{\mathrm{a}}$ & $3.47 \times 10^{5} \pm 0.45^{\mathrm{a}}$ \\
Plastic & $9.12 \times 10^{5} \pm 0.06^{\mathrm{a}}$ & $9.33 \times 10^{5} \pm 0.48^{\mathrm{a}}$ \\
Glass & $8.32 \times 10^{5} \pm 0.02^{\mathrm{a}}$ & $5.62 \times 10^{5} \pm 0.05^{\mathrm{a}}$ \\
Antibacterial plastic & $6.46 \times 10^{3} \pm 0.17^{\mathrm{b}}$ & $1.10 \times 10^{4} \pm 0.28^{\mathrm{b}}$ \\
\hline
\end{tabular}

474

$475{ }^{\dagger}$ Initial cells count $/ \mathrm{cm}^{2}: 2.01 \times 10^{6}$ live cells $/ \mathrm{cm}^{2}$ and $4.79 \times 10^{1} \mathrm{dead} /$ injured cells $/ \mathrm{cm}^{2}$.

$476 \quad{ }^{a, b}$ Values in columns for each surface are significantly different if the letters are

477 different $(p \leq 0.05)$.

478 
479 Table 2. Adherence and biofilm formation of Flavobacterium psychrophilum (cells $/ \mathrm{cm}^{2}$ ) to

480 stainless steel, plastic, glass, wood, and antibacterial plastic surfaces after 96 hours in

481 aquarium freshwater and lake water conditions.

482

\begin{tabular}{|c|c|c|c|c|}
\hline \multirow{3}{*}{ Surfaces } & \multicolumn{2}{|c|}{ Aquarium water } & \multicolumn{2}{|c|}{ Lake water } \\
\hline & \multicolumn{4}{|c|}{ Cells $^{\dagger}$} \\
\hline & Live & Injured or dead & Live & Injured or dead \\
\hline $\begin{array}{l}\text { Stainless steel } \\
\end{array}$ & $8.68 \times 10^{4} \pm 0.12^{\mathrm{a} A}$ & $1.46 \times 10^{5} \pm 0.12^{\mathrm{ab}}$ & $2.30 \times 10^{5} \pm 0.13^{\mathrm{aA}}$ & $1.54 \times 10^{5} \pm 0.39^{\mathrm{a}}$ \\
\hline Plastic & $1.09 \times 10^{5} \pm 0.08^{\text {а в }}$ & $5.87 \times 10^{4} \pm 0.11^{\mathrm{ab}}$ & $2.98 \times 10^{5} \pm 0.08^{\mathrm{aA}}$ & $3.09 \times 10^{5} \pm 0.50^{\mathrm{a}}$ \\
\hline Glass & $8.52 \times 10^{4} \pm 0.11^{\mathrm{aA}}$ & $1.25 \times 10^{5} \pm 0.12^{\mathrm{ab}}$ & $2.41 \times 10^{5} \pm 0.09^{\mathrm{a} \mathrm{B}}$ & $2.32 \times 10^{5} \pm 0.28^{\mathrm{a}}$ \\
\hline Wood & $1.11 \times 10^{5} \pm 0.10^{\mathrm{aA}}$ & $2.80 \times 10^{5} \pm 0.39^{\mathrm{a}}$ & $1.38 \times 10^{5} \pm 0.07^{\mathrm{b} \mathrm{A}}$ & $1.56 \times 10^{5} \pm 0.40^{\mathrm{a}}$ \\
\hline Antibacterial plastic & $2.88 \times 10^{2} \pm 0.13^{\mathrm{b} \mathrm{B}}$ & $1.39 \times 10^{4} \pm 0.34^{\mathrm{c}}$ & $6.03 \times 10^{3} \pm 0.17^{\mathrm{c} \mathrm{A}}$ & $2.25 \times 10^{4} \pm 0.19^{b}$ \\
\hline
\end{tabular}

483

$484{ }^{\dagger}$ Initial cells count $/ \mathrm{cm}^{2}: 2.14 \times 10^{6}$ live cells and $7.41 \times 10^{1}$ dead or injured cells. ${ }^{\text {a-c }}$ Values in

485 columns for each surface are significantly different if the letters are different $(p \leq 0.05) .{ }^{\text {A-B }}$

486 Values in rows for each surface for live cells results are significantly different if the letters are

487 different $(p \leq 0.05)$.

488

489

490 
491 Table 3. The differences (represented in $\log _{10}$ cells $/ \mathrm{cm}^{2}$ ) in the live-cell counts of $F$.

492 psychrophilum attached to plastic, glass, wood and antibacterial plastic compared with

493 stainless steel used as a positive control. Values higher than $2 \log _{10}$ represent surfaces with

494 bacteriostatic properties according to the conditions evaluated.

495

\begin{tabular}{cccc}
\hline \multirow{2}{*}{ Surfaces } & \multirow{2}{*}{ Humidity condition } & \multicolumn{2}{c}{ Freshwater or lake water conditions } \\
\cline { 3 - 4 } & & Freshwater aquarium & Lake water \\
\hline Stainless steel & 6.15 & 4.94 & 5.36 \\
\hline Plastic & 0.19 & +0.1 & +0.11 \\
Glass & 0.23 & 0.01 & +0.02 \\
Wood & - & +0.11 & 0.22 \\
Antibacterial plastic & $\underline{2.34}$ & $\underline{2.48}$ & 1.58 \\
\hline
\end{tabular}

496

497 Positive signs $(+)$ in $\log _{10}$ values at plastic, glass or wood surfaces represent an increase of

498 cells count respect to the stainless steel surface. No signs before the values represent a

499 reduction respect the stainless steel as a control. Reductions with more than $2 \log _{10}$ are

500 underlined.

501

502

503 


\section{Figure legends}

505

506 Figure 1. Examples of the fluorescence microscopy images of Flavobacterium

507 psychrophilum cells stained with the LIVE/DEAD ${ }^{\circledR}$ kit after $96 \mathrm{~h}$ of incubation. Live cells

508 appeared green in colour and dead or injured cell appeared red. In humidity condition: (a) live

509 cells forming biofilm, (b) round-shaped appearance of a dead cell indicated by an arrow on

510 stainless steel surfaces. In freshwater condition: (c) high density of dead or injured cells on

511 plastic surface, (d) the presence of live and dead or injured cells on glass surface. In lake

512 water condition: (e) wood, (f) zinc pyrithione plastic surface. All scale bars: $10 \mu \mathrm{m}$.

513

514 Figure 2. Mineral concentration in parts per billion ( $\mathrm{ppb}$ ) of freshwater aquarium and lake

515 water used to examine biofilm formation by F. psychrophilum. Abbreviations: Na-sodium, 516 Mg-magnesium, K-potassium and Ca-calcium.

517

518 

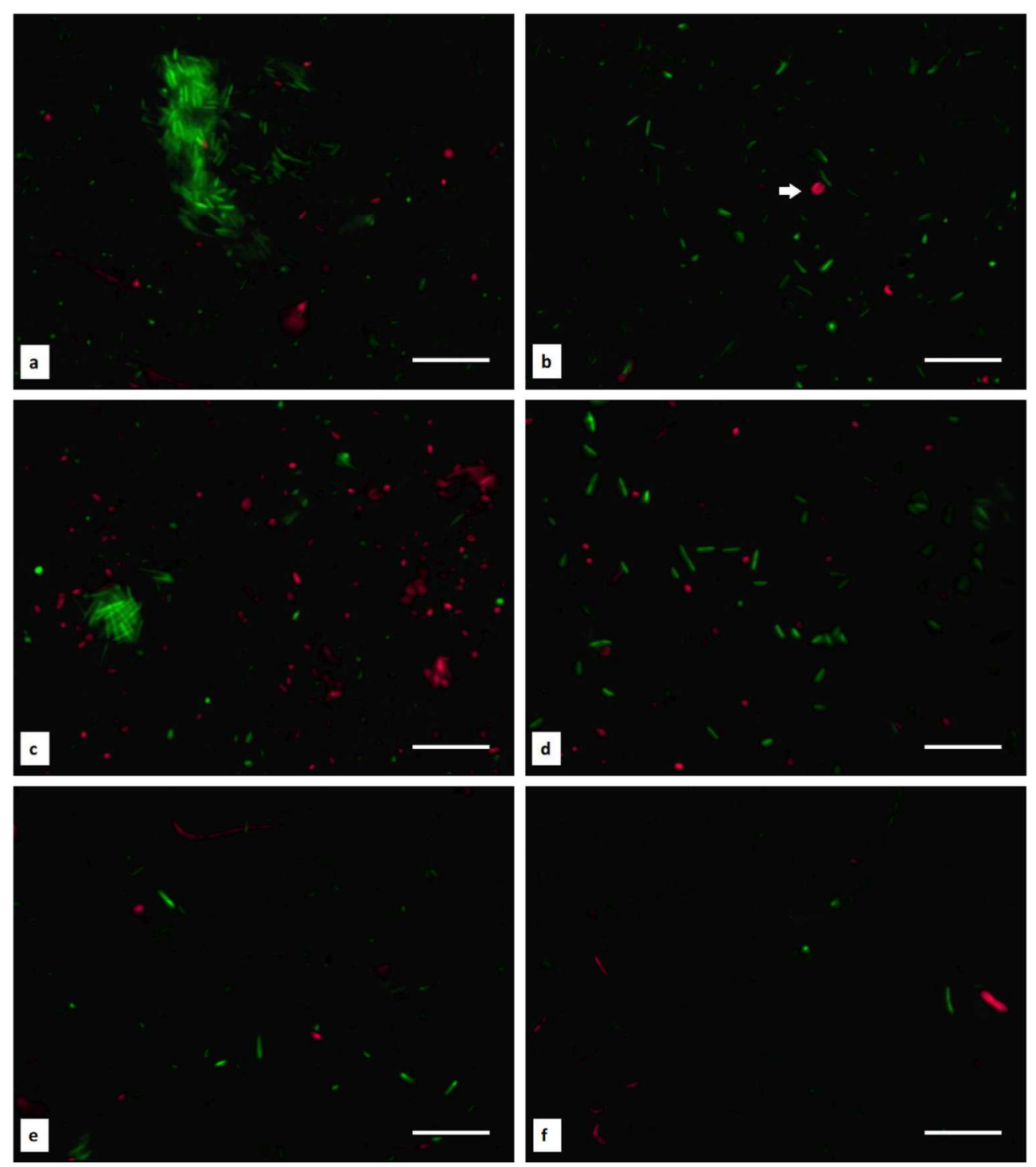

Figure 1. Examples of the fluorescence microscopy images of Flavobacterium psychrophilum cells stained with the LIVE/DEAD $®$ kit after $96 \mathrm{~h}$ of incubation. Live cells appeared green in colour and dead or injured cell appeared red. In humidity condition: (a) live cells forming biofilm, (b) round-shaped appearance of a dead cell indicated by an arrow on stainless steel surfaces. In freshwater condition: (c) high density of dead or injured cells on plastic surface, (d) the presence of live and dead or injured cells on glass surface. In lake water condition: (e) wood, (f) zinc pyrithione plastic surface. All scale bars: $10 \mu \mathrm{m}$.

$162 \times 183 \mathrm{~mm}(300 \times 300 \mathrm{DPI})$ 


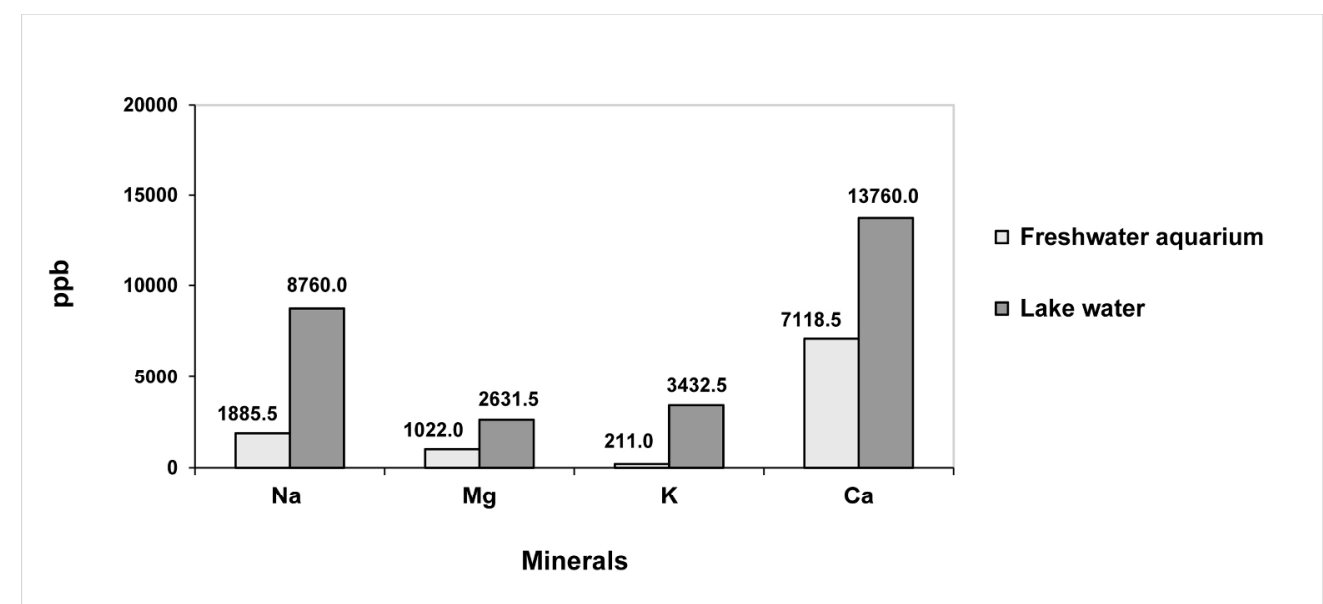

Figure 2. Mineral concentration in parts per billion $(\mathrm{ppb})$ of freshwater aquarium and lake water used to examine biofilm formation by F. psychrophilum. Abbreviations: Na-sodium, Mg-magnesium, K-potassium and $\mathrm{Ca}$-calcium.

$209 \times 96 \mathrm{~mm}(300 \times 300$ DPI $)$ 